\title{
Review
}

\section{Diagnostic Advances in Acute Viral Meningitis: Any Novelty for the Physician?}

\author{
Ozgur Karcioglu, MD ${ }^{\prime *}$; Ebru Yilmaz, MD²
}

'Emergency Physician, Department of Emergency Medicine, University of Health Sciences, Istanbul Education and Research Hospital, Istanbul, Turkey

${ }^{2}$ Emergency Physician, Deptartment of Emergency Medicine, Nizip Community Hospital, Gaziantep, Turkey

\section{"Corresponding author}

Ozgur Karcioglu, MD

Professor, Emergency Physician, Department of Emergency Medicine, University of Health Sciences, Istanbul Education and Research Hospital, Istanbul, Turkey; Gsm. +90.505.5252399; ORCID ID: 0000-0002-88I4-6164; E-mail: okarcioglu@gmail.com

Article information

Received: December 18 ${ }^{\text {th }}, 2018$; Revised: December 28 $8^{\text {th }}, 2018$; Accepted: January 3 ${ }^{\text {rd }}, 2019$; Published: January $7^{\text {th }}, 2019$

\section{Cite this article}

Karcioglu O,Yilmaz E. Diagnostic advances in acute viral meningitis:Any novelty for the physician?. Emerg Med Open J. 2019; 4(I): 20-24. doi: 10.17।40/EMOJ-4-I50

\section{| ABSTRACT |}

Acute viral meningitis (AVM) constitute an important cause of mortality and neurological morbidity within the last decades, in spite of all diagnostic and therapeutic advances in medical technology. Diagnostic procedures consist of lumbar puncture, hemoculture, complete blood cell count (including, leukocytes), procalcitonin, lactate and glucose to give an overall insight for disease; while polymerase chain reaction (PCR) and cerebrospinal fluid (CSF) analyses (urine reagent strips, glucose, protein, and microscopic examination) are used to diagnose herpetic meningeal involvement and most other viral infections affecting central nervous system (CNS). Findings in blood and CSF work-up after a clinical index of suspicion result in a high yield of diagnosis. Technological advances should be coupled with clinical findings to produce an accurate clinical management in the target population. This review is intended to analyze the epidemiology, clinical manifestation, findings on examination, and diagnostic tools to be utilized in patients suspected to have AVM in light of recent advances and research data, and to culminate up-to-date concept of AVM for primary care and emergency physicians.

\section{Keywords}

Acute viral meningitis; Aseptic meningitis; Acute viral encephalitis; Central nervous system infection; Diagnosis; Lumbar puncture.

\section{DIAGNOSTIC ADVANCES INF ACUTE VIRAL MENINGITIS: ANY NOVELTY FOR THE PHYSICIAN?}

\section{Definitions, and Characteristics in the Diagnosis}

A cute meningitis s described as an acute inflammation of meningeal membranes involved by causative agents. ${ }^{1}$

Viral agents can infect central nervous system (CNS) via various mechanisms including direct involvement and/or replication within the neural tissue leading to encephalitis, and/or meningitis. ${ }^{2}$ Acute meningitis in humans stems from various septic (bacterial and fungal) and aseptic (viral) pathogens. acute viral meningitis (AVM) (a.k.a. aseptic meningitis) consists of signs and symptoms of meningismus and pathologically boosted number of cells within the cerebrospinal fluid (CSF) in conjunction with a sterile bacterial hemoculture. ${ }^{3}$
Patients with AVM tends to be younger than those with bacterial meningitis. The prompt diagnosis of meningitis mainly compriseS direct work-up of the fluid and/or the presence of relevant antigenic material in the CSF following a lumbar puncture (LP). These tests are not highly sensitive, and they are not useful in the differential diagnosis in up to a half of the patients in the samples. ${ }^{4}$

Viallon et $\mathrm{al}^{5}$ demonstrated that best possible diagnosis is AVM in patients with negative direct CSF examination: up to $71 \%$ of these patients turned out to have AVM in a recent French study. ${ }^{5}$ Within the sample of 218 patients with AVM, the causative agent could be identified in eighty-five $(39 \%)$ : enteroviridae $(25 \%)$, herpes (9\%), varicella species and Paramyxoviridae (the latter two microorganisms constitute 5\%).

Acute viral encephalitis (AVE), on the other hand, is the 
result of human virus inflicting the CNS. There are two types of encephalitis-primary and secondary. Primary AVE is encountered in the situation of viral involvement of the CNS and the spinal cord directly, while secondary encephalitis (a.k.a. post-infectious encephalitis) is seen when an infection propagates to brain from another organ or system. The identification of the patients is mostly based on laboratory investigations. AVE is mostly a pathological diagnosis and represents inflammation of the brain parenchyma which may be visualized on magnetic resonance imaging (MRI). ${ }^{3}$ MRI can reveal focal or diffuse changes in signal intensity, cerebral edema, restricted diffusion, hemorrhages, necrosis, and enhancement. $^{6}$
Morbidity and mortality in viral meningitis are lower than bacterial infection, despite easier spread is common in patients with AVM. Viral meningitis is more frequent than bacterial in young adults, especially in women between the ages of the 20 s to $40 \mathrm{~s}^{3}$ An elaborate travel history may enlighten causes of viral etiology, e.g. Toscana Virus (South Europe), Tick-Borne Encephalitis (TBE) Virus (Europe), other meningococcal (Africa), West NileVirus (United States), Lyme disease (Europe and United States) and parasitic meningitis (e.g., Naegleria Fowleri or trypanosomiasis).

\section{Specific Agents}

Diagnostic features and characteristics of AVM caused by various specific viral agents were summarized in Table 1.

\begin{tabular}{|c|c|c|c|}
\hline Causative agent & Signs and symptoms & Involvement site detected on radiology (CT or MRI) & Notes on expected clinical course \\
\hline $\begin{array}{l}\text { Human immunodeficiency } \\
\text { virus (HIV) }\end{array}$ & Dementia, neurocognitive problems & Periventricular and white matter & $\begin{array}{l}\text { High mortality rate unless treated } \\
\text { accordingly. Antiretroviral treatment is } \\
\text { essential. }\end{array}$ \\
\hline Zika virus & $\begin{array}{l}\text { Although the course is generally mild, } \\
\text { neuroimmunological disorders, } \\
\text { meningoencephalitis, and myelitis can ocur. }\end{array}$ & $\begin{array}{l}\mathrm{CT} \text { and MRI:calcifications in the junction between } \\
\text { cortical and subcortical white matter, decreased } \\
\text { brain volume, ventriculomegaly. } \\
\text { MRI: Enlarged cisterna magna, delayed } \\
\text { myelination, malformations symmetrical in majority. }\end{array}$ & $\begin{array}{l}\text { Zikavirus is transmitted via bites } \\
\text { of infected arthropods. It causes } \\
\text { microcephaly, Guillain Barré syndrome, } \\
\text { neurological Zika syndrome, meningitis, } \\
\text { meningoencephalitis, and myelitis ensue } \\
\text { commonly. }\end{array}$ \\
\hline Varicella & $\begin{array}{l}\text { Altered mental status, fever, headache, may be } \\
\text { focal neurodeficits }\end{array}$ & Thalamus, cerebellum, cortex, basal ganglia & $\begin{array}{l}\text { Cerebral atrophy and/or } \\
\text { encephalomalacia can develop. }\end{array}$ \\
\hline Cytomegalovirus & $\begin{array}{l}\text { Commonest in neonates and } \\
\text { immunocompromised adults. }\end{array}$ & Cerebral hemispheres, periventricular & $\begin{array}{l}\text { Focal neurodeficits, hydrocephalus, and } \\
\text { developmental retardation can be noted. }\end{array}$ \\
\hline Herpes simplex virus type-I & Altered mental status, fever, seizures & Temporal and frontal lobes & $\begin{array}{l}\text { High fatality rate unless treated } \\
\text { accordingly. }\end{array}$ \\
\hline Herpes simplex virus type- 2 & $\begin{array}{l}\text { Mostly neonatal disease. Altered mental } \\
\text { status, fever, seizures }\end{array}$ & Global/diffuse involvement of the brain & $\begin{array}{l}\text { High fatality rate unless treated } \\
\text { accordingly. Encephalomalacia, } \\
\text { paranchymal calcification can develop. }\end{array}$ \\
\hline Creutzfeldt-Jakob's Disease & $\begin{array}{l}\text { Rapidly deteriorated dementia, myoclonic } \\
\text { jerks }\end{array}$ & Thalamus, cerebral, cortex, basalganglia & Rapidly ensuing cerebral atrophy \\
\hline $\begin{array}{l}\text { Tick borne encephalitis } \\
\text { (TBE) }\end{array}$ & $\begin{array}{l}\text { In the vast majority of cases, an infection with } \\
\text { TBEV has a subclinical course. }\end{array}$ & $\begin{array}{l}\text { The thalamus is the most common site of } \\
\text { involvement. In MRI, lesion contrast wasstrong, with } \\
\text { a hyperintense T2 signal of nerveroots, plexuses } \\
\text { and peripheral nerves. The extent of spatial lesions } \\
\text { and patterns exceeded the clinical manifestations } \\
\text { of disease }\end{array}$ & $\begin{array}{l}\text { In some cases, it leads to brain edema, } \\
\text { meningitis, meningoencephalitis, } \\
\text { myelitis, or meningoencephaloradiculitis. } \\
\text { Decompressive craniectomy might be } \\
\text { considered in extremecases. }\end{array}$ \\
\hline West Nile virus & $\begin{array}{l}\text { Mostly neuroinvasive, it causes meningitis, } \\
\text { encephalitis, or acute flaccid paralysis, mostly } \\
\text { in adult and elderly males. }\end{array}$ & $\begin{array}{l}\text { Cortical thinning in both hemispheres-primarily in } \\
\text { the frontal and limbic cortices. Regional atrophy in } \\
\text { the cerebellum, brainstem, thalamus, putamen, and } \\
\text { globus pallidus. }\end{array}$ & $\begin{array}{l}\text { Death is rare. Mostly involves adults } \\
\text { and elderly males. Weakness, decreased } \\
\text { reflexes can be seen. }\end{array}$ \\
\hline
\end{tabular}

Herpes simplex viruses (HSV-1 and HSV-2): These are viruses which trigger a latent infection in the neurons of the dorsal root ganglia.

HSV encephalitis is a widespread cause of fatal encephalitis in the world. Temporal lobe abnormalities are among the most common radiological culprits. ${ }^{7}$ Among the causes of AVE, HSE is different from most because it is treatable.

Varicella-zoster virus (VZV): This encephalitis can be remarkable following primary infection, and reactivation of VZV may lead to AVE. Meanwhile, VZV invasion of cerebral arteries triggers vasculopathy, which is evident as an acute cerebrovascular accident or stroke. ${ }^{7}$
West Nile virus: These triggers neurocognitive outcomes in patients. In a large series, Murray et $\mathrm{al}^{8}$ reported that abnormal neurological findings were noted in almost half of the patients, with a majority being unilateral. ${ }^{8}$ Since no effective treatment measures are in use, preventive strategies against infection are of vital importance.

Zika virus infections: These are known to inflict severe cerebral damage due to congenital infection. Around four-fifths of the cases are asymptomatic and symptomatic cases are mostly mild. ${ }^{9,10}$ The mosquito Aedes aegypti was most commonly accused of viral transmission, followed by sexual transmission, vertical transmission, and blood transfusion. ${ }^{11}$ Its diagnosis is somewhat elusive. Blood and urine testing were proved most useful in acute diagnosis. In case series from Brazil, only around one-third of children are 
identified positively with IgM antibodies against the agent in CSF. ${ }^{12}$ It is most recognized with a constellation of radiological findings coupled with typical clinical features such that microcephaly and neuroimmunological diseases such as Guillain Barré syndrome and neurological Zika syndrome. ${ }^{13}$ Since important cerebral impairment is encountered on imaging in a majority of the infected individuals, the disease should be in the differential diagnosis list of the emergency practitioner in the inflicted or 'endemic' areas.

Primary human immunodeficiency virus type 1 (HIV-1): This infection can affect almost all parts of the CNS. ${ }^{14}$ Both neurologist and the emergency care provider should be cognizant of symptomatic primary HIV infection, to allow an expedient and accurate diagnosis of HIV infection and the consideration of timely antiretroviral therapy. ${ }^{15} \mathrm{HIV}$-infected patients can develop Cryptococcus meningitis, toxoplasmosis, primary CNS lymphoma, and progressive multifocal leukoencephalopathy. ${ }^{16} \mathrm{HIV}$ can also induce acute aseptic meningitis manifested with fever, headaches, and meningismus.

Tick-Borne encephalitis (TBE): It is an infection triggered by an RNA virus which is prevalent in some parts of Europe and Asia. ${ }^{17}$ The causative agent is mostly transmitted by tick bites but also occasionally by unpasteurized milk from goats. ${ }^{18}$ Turkish sheep encephalitis virus and Greek goat encephalitis viruses are thought to be included in the TBEV species. ${ }^{19,20}$ The majority of patients are middle-aged and elderly male. ${ }^{21}$

TBE ensues after incubation of around eight days following tick bite. ${ }^{22}$ Especially in patients inflicted by European form of the agent, TBE can go unnoticed in about one-third of the involved ones and mostly follows a biphasic course.

In a majority of patients, the infection has a mild or 'subclinical' course. However, in some cases, it leads to AVM and/or AVE and relevant neurological symptoms. The disease manifests as AVM in around half of the patients, as AVE in $40 \%$ and as encephalomyelitis in $10 \% .{ }^{18}$ In about one-third of meningitis cases, meningoencephalitis or meningomyelitis is developed. ${ }^{23} \mathrm{CNS}$ and spinal imaging have a low yield to diagnose AVE and/or AVM, but it can be of value in the differential. In 2016, Lenhard et $\mathrm{al}^{21}$ reported that significantly more MRI abnormalities of any kind were seen in those with meningoencephaloradiculitis (58.3\%) than in $\operatorname{ME}(17.4 \%){ }^{21}$

Post-encephalitic syndrome may be the complication of the infection, presenting with neurological symptoms. Vaccination against TBE is recommended for the whole population older than 1 -year in certain endemic areas. ${ }^{24} \mathrm{~A}$ tick bite does not warrant post -exposure prophylaxis.

Ebola virus: It is one of the agents causing biggest death tolls known so far. The entity mostly manifests with febrile chills, cephalalgia, copious vomiting and/or gastroenteritis, and may deteriorate to hemorrhagia, AVE and seizures. Following an Ebola outbreak in West Africa, neurologic complications including seizures, memory loss, headaches, cranial nerve abnormalities and tremor were noted in a large number of patients. ${ }^{25}$ The mechanisms how Ebola affects the CNS is unknown, and treatment is still mainly supportive.

\section{Signs and symptoms}

Those with bacterial meningitis commonly look worse or more ill than those with nonbacterial illness. AVE is marked by cognitive malfunction and patients commonly have a stiffness of the neck muscles, but this feature is mild when compared to ABM. Those with viral meningoencephalitis have both neck stiffness and mental confusion. ${ }^{26}$ Patients with AVE mostly share similar clinical characteristics and findings to indicate a specific causative viral culprit are commonly elusive.

AVM is most difficult to diagnose, because "classical" presentation for meningitis i.e., a stiff neck, altered mental status and high core temperature- are seldom present in the patients.

In French study patients with AVM had similar, and even higher mean temperature and nuchal rigidity than bacterial cases (mean temperatures were 39.1 vs. $38.9 \mathrm{C}$ and nuchal rigidity $55 \%$ vs. $46 \%$, respectively). ${ }^{5}$ Headache is noted more commonly in AVM than bacterial infections $(72 \% v$ s. $40 \%)$. In contrast, confusion is more prevalent in bacterial meningitis than AVM.

\section{DIAGNOSTIC ADVANCES, BIOMARKERS FOR IDENTIFICATION}

Apart from history and clinical findings, laboratory adjuncts are of value in certain specific viral infections. A specific pathogen diagnosis is based on serum and/or CSF tests. The CSF Gram stain and CSF lactic acid levels provide the most rapid, reliable and cost-effective tests to diagnose bacterial infection. ${ }^{26} \mathrm{CSF}$ lactic acid levels have long been known to be of value in expedient diagnosis of bacterial meningitis and distinguish from nonbacterial CNS diseases such asAVE and AVM. ${ }^{27}$ To be more specific, CSF lactate levels above $6 \mathrm{~mm} / \mathrm{L}$ forms the basis of reliable diagnosis of bacterial meningitis. ${ }^{26}$ Patients with AVE involve mainly parenchymal brain and infection of the CSF is a minor component of the disease process. Therefore, most patients with AVE have negative culture results of viral pathogens in the samples of CSF. In those with AVE, the electroencephalogram (EEG) usually demonstrates global bilateral symmetrical slow-wave activity. ${ }^{26}$ In patients with AVE, the EEG/MRI can give clues indicating a particular part of the brain, such as basal ganglia, West Nile encephalitis etc. ${ }^{28,29}$

Patients with AVE/AVM have CSF WBC counts higher than those with ABM. Neurosyphilis, AVE, AVM, tuberculosis are commonly accompanied by the lymphocytic pleocytosis in the CSF and these mostly present initially with a PMN dominance. CSF pleocytosis in ABM is $>90 \%$ PMNs, especially if not administered antibiotics yet. ${ }^{28,29}$ Likewise, atypical lymphocytes are suggestive of certain viral agents, for example, EBV, VZV. ${ }^{26}$ 
Classically, HSV encephalitis is associated with red blood cells. In Herpetic AVE, red blood cells are proportional to the degree of frontal/temporal damage. Interestingly, CSF lactate levels are proportional to the number of red blood cells found in CSF.

Next-generation sequencing (NGS) is the diagnostic modality of choice to screen for viral deoxyribo nucleic acid (DNA) in CSF in cases with strong suspicion for AVM or AVE. ${ }^{30}$

Polymerase chain reaction (PCR) is used to diagnose herpetic meningeal involvement. Of note, identification of HSV DNA in the CSF by PCR is of diagnostic value in herpetic meningoencephalitis. $^{7}$ In patients with AVE due to viruses with a CSF result masquerading as $\mathrm{ABM}$, such that in acute herpetic meningoencephalitis, normal CSF lactate levels can be used to rule out $\mathrm{ABM} \cdot{ }^{26}$

Routine workup on blood samples (e.g. leukocytes, neutrophil ratios and platelets), rarely give clues in the diagnosis of AVM. Bacterial infection may be identified in the work-up of the CSF via an LP to be performed in suspicion of bacterial origin of meningoencephalitis. Likewise, Gram stain/culture of the pathogen is mostly useless in viral infections of CNS.

PCR is used to identify VZV DNA in the CSF and may be used as a diagnostic clue for encephalitis and/or vasculopathy. $^{7}$ In a case series, mean CD4 T-cell count was around $142 \times 10^{6}$ cells/L.

Etiologic diagnosis of TBE is only made on basis of laboratory analyses, namely, reverse transcription-PCR (RT-PCR). ${ }^{23}$ The technique is used to verify the presence of virus in the blood and CSF. The suspected diagnosis is verified by the detection of TBEV-specific IgM and IgG antibodies in the sera and the presence of elevated cell counts in CSF. ${ }^{18}$

A simple concurrent bedside glucose measurement in the samples from blood and CSF can allow rapid identification of AVM. ${ }^{31}$ The best cut off point for the proportion of CSF over blood glucose produced via a point-of-care glucometer has been noted as 0.46 , (it has $94.1 \%$ sensitivity, $91 \%$ specificity, and a positive likelihood ratio of 10 in discerning these two entities). The above mentioned practical modality carries the potential to provide faster diagnostic evaluation of the disease.

Viallon et $\mathrm{al}^{5}$ reported that serum PCT and CSF lactate are the best markers for differentiating between bacterial infection and AVM, even in the lack of microbiologic biomarkers on presentation and/or on admission to hospital. ${ }^{5}$

\section{Role of Neuroimaging}

CT or MRI can be utilized to rule out CNS mass lesions, e.g., brain abscess, brain tumors, bleed. These modalities may also be of value in the differential diagnosis of AVM, such that sarcoid meningitis and carcinomatous meningitis.

\section{CONCLUSION}

AVM is an outstanding emergency which can lead to morbidity and mortality all over the world. Findings in blood and CSF work-up after a clinical index of suspicion result in a high yield of diagnosis. Technological advances should be coupled with clinical findings to produce accurate clinical management in the target population.

\section{CONFLICTS OF INTEREST}

The authors declare that they have no conflicts of interest.

\section{REFERENCES}

1. Prasad K, Karlupia N. Prevention of bacterial meningitis: An overview of cochrane systematic reviews. Respir Med. 2007; 101(10) :2037-2043. doi: 10.1016/j.rmed.2007.06.030

2. Bookstaver PB, Mohorn PL, Shah A, et al. Management of viral central nervous systemInfections: A primer for clinicians. J Cent Nerv Syst Dis. 2017; 9: 1179573517703342. doi: $10.1177 / 1179573517703342$

3. McGill F, Heyderman RS, Panagiotou S, Tunkel AR, Solomon T. Acute bacterial meningitis in adults. Lancet. 2016; 388(10063): 3036-3047. doi: 10.1016/S0140-6736(16)30654-7

4. van de Beek D, de Gans J, Spanjaard L, Weisfelt M, Reitsma JB, Vermeulen M. Clinical features and prognostic factors in adults with bacterial meningitis. N Engl J Med. 2004; 351: 1849-1859.

5. Viallon A, Desseigne N, Marjollet $\mathrm{O}$, et al. Meningitis in adult patients with a negative direct cerebrospinal fluid examination: Value of cytochemical markers for differential diagnosis. Crit Care. 2011; 15(3): R136. doi: 10.1186/cc10254

6. Bertrand A, Leclercq D, Martinez-Almoyna L, Girard N, Stahl JP, De-Broucker T. MR imaging of adult acute infectious encephalitis. Med Mal Infect. 2017; 47(3): 195-205. doi: 10.1016/j.medmal.2017.01.002

7. Kawada JI. Neurological disorders associated with human alphaherpesviruses. Adv Exp Med Biol. 2018; 1045: 85-102. doi: 10.1007/978-981-10-7230-7_5

8. Murray KO, Nolan MS, Ronca SE, et al. The neurocognitive and MRI outcomes of west nile virus infection: Preliminary analysis using an external control group. Front Neurol. 2018; 9: 111. doi: 10.3389/fneur.2018.00111

9. Levi ME. Zika virus: A cause of concern in transplantation?. Curr Opin Infect Dis. 2017; 30(4): 340-345. doi: 10.1097/ QCO.0000000000000384

10. Yun SI, Lee YM. Zika virus: An emerging flavivirus. J Microbiol. 2017; 55(3): 204-219. doi: 10.1007/s12275-017-7063-6 
11. Dias IKR, Sobreira CLDS, Martins RMG, et al. Zika virus: - A review of the main aspects of this type of arbovirosis. Rev Soc Bras Med Trop. 2018; 51(3): 261-269. doi: 10.1590/0037-8682-01302018

12. Aragao MDFV, Linden VVD, Brainer-Lima AM, et al. Clinical features and neuroimaging (CT and MRI) findings in presumed Zika virus related congenital infection and microcephaly: Retrospective case series study. BMJ. 2016; 353: i1901. doi: 10.1136/ bmj.i3182

13. Russo FB, Beltrão-Braga PCB. The impact of Zika virus in the brain. Biochem Biophys Res Commun. 2017; 492(4): 603-607. doi: 10.1016/j.bbrc.2017.01.074

14. Spudich S, González-Scarano F. HIV-1-related central nervous system disease: Current issues in pathogenesis, diagnosis, and treatment. Cold Spring Harb Perspect Med. 2012; 2(6): a007120. doi: 10.1101/cshperspect.a007120

15. Brew BJ, Garber JY. Neurologic sequelae of primary HIV infection. Handb Clin Neurol. 2018; 152: 65-74. doi: 10.1016/B9780-444-63849-6.00006-2

16. Seethala R, Takhar SS. Viruses. In: Walls R, Hockberger R, Gausche-Hill M (eds), Rosen's Emergency Medicine Concepts and Clinical Practice. $9^{\text {th }}$ Edn. Amsterdam, Netherlands: Elsevier. 2017. 15981618.

17. Du Four S, Mertens R, Wiels W, De Keyser J, Bissay V, Flamez A. Meningoencephaloradiculitis following infection with tick borne encephalitis virus: Case report and review of the literature. Acta Neurol Belg. 2018; 118(1): 93-96. doi: 10.1007/s13760-017-0873-9

18. Kaiser R.[Tick-borne encephalitis]. Nervenarzt. [In: German]. 2016; 87(6): 667-80. doi: 10.1007/s00115-016-0134-9

19. Grard G, Moureau G, Charrel RN. Genetic characterization of tick-borne flaviviruses: New insights into evolution, pathogenic determinants and taxonomy. Virology. 2007; 361: 80-92. doi: 10.1016/j.virol.2006.09.015

20. Lindquist L. Tick-borne encephalitis. Handb Clin Neurol. 2014; 123: 531-559. doi: 10.1016/B978-0-444-53488-0.00025-0

21. Lenhard T, Ott D, Jakob NJ, et al. Predictors, neuroimaging characteristics and long-term outcome of severe European tick- borne encephalitis: A prospective cohort study. PLoS One. 2016; 11(4): e0154143. doi: 10.1371/journal.pone.0154143

22. Kaiser R. The clinical and epidemiological profile of tickborne encephalitis in southern Germany 1994-98: A prospective study of 656 patients. Brain. 1999; 122: 2067-2078. doi: 10.1093/ brain/122.11.2067

23. Hrnjaković Cvjetković I, Cvjetković D, et al. Tick-borne encephalitis virus infection in humans. Med Pregl. 2016; 69(3-4): 9398.

24. Taba P, Schmutzhard E, Forsberg P, et al. EAN consensus review on prevention, diagnosis and management of tick-borne encephalitis. Eur J Neurol. 2017; 24(10): 1214-e61. doi: 10.1111/ ene. 13356

25. Billioux BJ, Smith B, Nath A. Neurological complications of ebola virus infection. Neurotherapeutics. 2016; 13(3): 461-470. doi: 10.1007/s13311-016-0457-z

26. Cunha BA. The clinical and laboratory diagnosis of acutemeningitis and acuteencephalitis. Expert Opin Med Diagn. 2013; 7(4): 343-364. doi: 10.1517/17530059.2013.804508

27. Lannigan R, Mac Donald MA, Marrie TJ, Haldane EV. Evaluation of cerebrospinal fluid lactic acid levels as an aid in differential diagnosis of bacterial and viral meningitis in adults. J Clin Microbiol. 1980; 11(4): 324-327.

28. Cunha B, Halperin JJ. Clinical approach in encephalitis. In: Halperin JJ, ed. Encephalitis: Diagnosis and Treatment. Boca Raton, Florida, US: CRC Press. 2008. 1-19.

29. Booss J, Esiri M. Diagnostic evaluation. In: Booss J, Esiri M, eds. Viral Encephalitis in Humans. Washington, DC: ASM Press. 2003. 21-96.

30. Guan H, Shen A, Lv X, et al. Detection of virus in CSF from the cases with meningoencephalitis by next-generation sequencing. J Neurovirol. 2016; 22(2): 240-245. doi: 10.1007/s13365-0150390-7

31. Rousseau G, Asmolov R, Grammatico-Guillon L, et al. Rapid detection of bacterial meningitis using a point-of-care glucometer. Eur J Emerg Med. 2017; 26(1): 41-46. doi: 10.1097/ MEJ.0000000000000495 